\title{
REFLEXÕES PARA UMA ABORDAGEM CRÍTICA DA PAISAGEM: VALOR E ESTÉTICA DAS MERCADORIAS URBANAS
}

\author{
Gabriel Augusto Coêlho de Santana \\ Universidade Federal de Pernambuco - UFPE \\ gabriel.coelho@ufpe.br \\ Rodrigo Dutra Gomes \\ Universidade Federal de Pernambuco - UFPE \\ rdutragomes@gmail.com
}

\begin{abstract}
RESUMO
Buscamos neste artigo desenvolver uma abordagem da paisagem pela qual seja possível compreender a materialidade das formas e as subjetividades de quem as interpretam como componentes da disputa dos agentes produtores do espaço urbano nas as cidades. Entendendo as paisagens como maneiras de ver, a construção desta abordagem crítica se realiza a partir de sua articulação com categorias como valor de uso, valor de troca, bem como o conceito de estética da mercadoria. Com o suporte desde conjunto de conceitos, pensamos as paisagens da cultura dominante como aquelas produzidas tendo a realização do valor de troca como finalidade, a partir da produção de paisagens como uma estética de mercadorias urbanas condizentes com os referentes ideológicos da cultura dominante; e paisagens da cultura popular, onde a perspectiva dos usos como a moradia e o trabalho se sobrepõem a busca pela obtenção do valor de troca. A partir da construção desta abordagem, discutimos um conflito que envolve a participação de moradores e moradoras, representantes do Estado e de agentes imobiliários no Recife.
\end{abstract}

Palavras-chave: Paisagem. Valor. Estética da Mercadoria. Recife.

\section{REFLEXIONES PARA UN ENFOQUE CRÍTICO DEL PAISAJE: VALOR Y ESTÉTICA DE LAS MERCANCÍAS URBANAS}

\begin{abstract}
RESUMEN
Buscamos en este artículo desarrollar un enfoque del paisaje por el cual sea posible comprender la materialidad de las formas y las subjetividades de quienes las interpretan como componentes de la disputa de los agentes productores del espacio urbano en las ciudades. Entendiendo los paisajes como maneras de ver, la construcción de este enfoque crítico se realiza a partir de su articulación con categorías como valor de uso, valor de cambio, así como con el concepto de estética de la mercancía. Con el apoyo de este conjunto de conceptos, pensamos los paisajes de la cultura dominante como aquellas producidas teniendo el valor de cambio como finalidad, a partir de la producción de paisajes con una estética de mercancías urbanas, concordantes con los referentes ideológicos de la cultura dominante; y paisajes de la cultura popular, donde usos como la vivienda y el trabajo se superponen a la búsqueda por la obtención del valor de cambio. A partir de la construcción de este enfoque, discutimos un conflicto que involucra la participación de residentes y moradores, representantes del Estado y de agentes inmobiliarios en Recife.
\end{abstract}

Palabras clave: Paisaje. Valor. Estética de la Mercancía. Recife.

$\begin{array}{llllll}\text { Caminhos de Geografia } & \text { Uberlândia-MG } & \text { v. 20, n. } 71 & \text { Setembro/2019 } & \text { p.119-136 } & \text { Página } 119\end{array}$




\section{INTRODUÇÃO}

Nosso propósito neste artigo é compartilhar reflexões para a construção de uma abordagem crítica da paisagem. Para fazê-lo, iniciamos compartilhando duas questões que se colocam como premissas deste debate: que paisagem? Qual abordagem crítica? Na Geografia, diversas são as formas de abordar as paisagens; portanto, é necessário que explicitemos qual o conceito que estamos utilizando para tais reflexões. Aqui trabalhamos com a ideia da paisagem como "'maneira de ver', uma maneira de compor e harmonizar o mundo externo em uma 'cena', uma unidade visual" (COSGROVE, 2004). Esta escolha não desconhece, como vínhamos dizendo, as inúmeras outras concepções de paisagem com as quais geógrafas e geógrafos têm buscado realizar suas pesquisas. No entanto, é a partir das maneiras de ver que pretendemos contribuir para a construção de uma abordagem da paisagem em que seja possível refletir sobre como a materialidade das formas e a subjetividade das interpretações de quem as produz compõem a disputa dos agentes produtores do espaço pela cidade.

A partir da apreensão da materialidade das formas, a pessoa que observa constrói uma interpretação daquilo que the chegou através dos sentidos. Essa interpretação do que foi apreendido, no entanto, não se realiza desconsiderando a carga de informações, experiências e valores anteriormente construídos pela observadora em sua trajetória de vida. A maneira de ver é, nesse sentido, uma composição entre o que se pôde apreender pelos sentidos e as informações que o sujeito utiliza para ler a realidade. Para Berdoulay, essa carga de informações seria "um reservatório de ideias fundamentais, um conjunto de representações que o indivíduo utiliza para justificar ou guiar suas condutas, especialmente diante de situações particulares" (BERDOULAY, 2012, p. 113), chamada referentes ideológicos.

Pensando as paisagens como maneiras de ver constituídas em conformidade com os referentes ideológicos do sujeito que as observa, podemos inferir que tão diversas serão as paisagens quanto são diversos os pontos de vista e quem os carrega para a construção de sua visão mundo. $\mathrm{Da}$ mesma forma, a construção dos referentes ideológicos de cada sujeito é um processo em constante movimento. Parodiando a assertiva de Heráclito, para o qual não se pode adentrar duas vezes 0 mesmo rio (pois as águas não são as mesmas e o próprio ser já se modificou), poderíamos dizer que não se pode observar duas vezes uma mesma paisagem, pois as formas não são mais as mesmas e os referentes ideológicos de quem as observa também se modificaram no curso da vida.

Acerca da construção dos referentes ideológicos, aspecto importante para a perspectiva com a qual abordamos o conceito de paisagem, cabe salientar também que embora estes sejam guias para a percepção dos indivíduos, são construídos em meio a contradições sociais. Em uma sociedade culturalmente diversa e economicamente desigual, a construção dos referentes ideológicos guarda relação com tais características, expressando as diversidades e desigualdades existentes. Sobre as relações cultura e poder, afirma Cosgrove que o segundo é "mantido e reproduzido, até um ponto consideravelmente importante, por sua capacidade de projetar e comunicar, por quaisquer meios disponíveis e por todos os outros níveis e divisões sociais, uma imagem do mundo consoante com sua própria experiência" (COSGROVE, 2004, p. 230). Embora existam, em meio às diversidades e desigualdades entre sujeitos, diversas maneiras de ver, a capacidade de um determinado grupo social de comunicar e massificar sua experiência como representação correta do mundo assegura que o poder - econômico e político - deste agrupamento se expresse culturalmente.

Recorremos a um exemplo para tornar isso mais claro: a ideia de segurança. A construção de muros altos em prédios e condomínios que são interpretadas como formas de segurança do ponto de vista dos que moram em tais empreendimentos e utilizam o carro como meio de transporte, podem ser interpretadas por pessoas que transitam pela cidade - prioritariamente como pedestres - como paisagens de insegurança. A propaganda do empreendimento veiculada na televisão, no entanto, não considera as múltiplas percepções sobre as formas, mas ressalta aquelas perspectivas que são convenientes do ponto de vista de quem se espera atingir, o comprador. Assim, a disputa sobre qual "maneira de ver" prevalece como hegemônica passa pelo que Althusser (1980) definiu como Aparelhos Ideológicos de Estado (das leis, da família, da escola, dos meios de comunicação, da arte, etc), através dos quais a incorporação de valores na sociedade se realiza. Ou seja, as maneiras de ver a paisagem pelos agentes produtores do espaço passam por filtros de referentes ideológicos (BERDOULAY, 2012) e aparelhos ideológicos (ALTHUSSER, 1980) que influenciam sua percepção. 
$\mathrm{Na}$ segunda questão-premissa: qual abordagem crítica? A terminologia "crítica" em Geografia designa, segundo Moraes (2005), uma postura política frente à ordem constituída e um posicionamento dos autores no sentido da transformação da realidade social. Ainda segundo Moraes, no que concerne às metodologias na Geografia Crítica, "esta apresenta um mosaico de orientações metodológicas bastante variado: estruturalistas, existencialistas, analíticos, marxistas (em suas várias nuances), ecléticos etc." (Ibdem, p. 131). Tal definição do que seria a Geografia Crítica engloba uma série de abordagens distintas, cujo ponto de convergência reside principalmente no engajamento social da pesquisa. Já para Capel (1981) a Geografia Crítica expressa, no âmbito das ciências geográficas, um movimento que alcançou de forma semelhante as demais ciências sociais. Iniciado na Europa e Estados Unidos, tal movimento busca construir uma alternativa frente as abordagens acadêmicas tradicionais, recorrendo a teoria marxista para a elaboração dessa abordagem crítica.

Quando refletimos sobre uma abordagem crítica da paisagem, pretendemos contribuir com a construção de uma forma de empregar este conceito através da qual as contradições da sociedade se expressam em maneiras de ver, reveladoras dos pressupostos ideológicos de seu observador e de suas intencionalidades. É com esta perspectiva que começamos por articular a paisagem com conceitos próprios da abordagem crítica, pensando a paisagem na sua relação com a dialética, as ideologias e a cultura. Em seguida, introduzimos na discussão a categoria marxiana do valor em sua dupla manifestação - uso e troca - e a relação desta perspectiva de Haug (1997) sobre a estética das mercadorias.

Embora o propósito que anunciamos seja o de compartilhar reflexões de cunho teórico, articulado conceitos e categorias, o fazemos associando a um caso que nos permita visualizar a relação entre teoria e empiria. Nesse sentido, a partir da articulação de conceitos supramencionada, discutimos a produção de maneiras de ver a partir da proposição de dois empreendimentos privados no Sudoeste do Recife que consorciam a construção de edifícios para um "bairro planejado" e um shopping na localidade. Circundando a área do empreendimento, ações do Estado e de moradores e moradoras se desenvolvem, tais como a construção de um parque pela prefeitura municipal e ocupações urbanas consolidadas e recentes. Tendo em vista essa multiplicidade de agentes, desde o processo de licenciamento até as peças publicitárias e de divulgação, fica ressaltado que o interesse por parte dos empreendedores na produção de uma paisagem como componente estético das mercadorias urbanas é parte de uma disputa que se realiza no plano ideológico, para além da disputa pelo controle e usos do terreno.

Quanto aos procedimentos para a realização do trabalho, iniciamos por um levantamento bibliográfico orientado para elencar o conjunto e conceitos e categorias que articulados, em nosso entendimento, constituiriam um arcabouço mínimo para uma leitura crítica da paisagem. Tal levantamento bibliográfico ancorou-se em trabalhos de perspectivas diversas do pensamento marxista (ALTHUSSER, 1980; KONDER, 2008; LOWY, 2015; MARX, 2013; MORAES, 2005; PAULO NETTO, 2011), como também de autores associados ao pensamento frankfurtiano (ADORNO e HORKHEIMER, 1998; HAUG,1997). Dialogando com este conjunto teórico está a paisagem, conforme descreveu Cosgrove (2004) no âmbito da chamada Geografia Cultural Radical. No que diz respeito ao trato do caso empírico, foi realizado levantamento documental acerca do referido empreendimento, recorrendo as seguintes fontes: órgãos públicos, veículos formais e informais de comunicação, anúncios publicitários e registros fotográficos. Foram ainda realizados trabalhos de campo com a finalidade de conhecer a situação da área na atualidade, complementando as informações obtidas no levantamento documental.

Para a exposição das ideias neste artigo, começaremos por refletir sobre as relações entre paisagem e ideologia, compreendendo a primeira como expressão da segunda a partir das contribuições de Cosgrove (2004). Em seguida, discutiremos como a paisagem tem se tornado instrumento para a realização do valor de troca, se conformando como estética das mercadorias urbanas. Por fim, a partir da análise iconográfica de propagandas, falas de representantes empresariais para veículos de comunicação, logomarcas e maquetes virtuais, discutiremos em que medida empreendimentos 
imobiliários no Sudoeste do Recife valem-se deste uso estético da paisagem como instrumento para valorização das mercadorias.

\section{PAISAGEM E DIALÉTICA, IDEOLOGIA E CULTURA}

Reivindicar a construção de uma abordagem crítica da paisagem implica em colocá-la em diálogo com outras categorias, conceitos e com os fundamentos do que chamamos da vertente crítica em Geografia. Ao parodiarmos a assertiva de Heráclito em certo sentido iniciamos o primeiro diálogo: a relação entre paisagem e dialética. Nos escritos do filósofo grego são encontrados alguns dos fundamentos do que modernamente seria considerado o pensamento dialético, como a ideia de constante movimento presente na célebre frase a que nos referimos anteriormente. Contudo, a perspectiva de dialética do campo crítico nas ciências sociais e na Geografia é referenciada no materialismo histórico e dialético de Marx e Engels. Contrapondo a perspectiva idealista de Hegel, Marx afirma que o método por eles proposto

difere do método hegeliano, sendo a ele inteiramente oposto. Para Hegel, o processo do pensamento [...] é o criador do real, e o real é apenas sua manifestação externa. Para mim, ao contrário, o ideal não é mais do que o material transposto para a cabeça do ser humano e por ele interpretado (MARX apud. PAULO NETTO, 2011, p. 21).

Pensar as paisagens como maneiras de ver a luz desta perspectiva de dialética significaria entendêlas como uma transposição da realidade material para a consciência humana, seguida de sua interpretação. Porém, é a partir de sua subjetividade que o sujeito torna a agir, transformando materialmente a realidade. Nesse sentido, o que se vislumbra é uma relação entre a produção social do espaço material e sua apreensão intelectual pelos sujeitos. A este respeito, Moraes afirmou

\footnotetext{
Esta produção social do espaço material, esta valorização objetiva da superfície da Terra, esta agregação de trabalho ao solo, passa inapelavelmente pelas representações que os homens estabelecem acerca do seu espaço. Não há humanização do planeta sem uma apropriação intelectual dos lugares, sem uma elaboração mental dos dados da paisagem, enfim, sem uma valorização subjetiva do espaço (MORAES, 2005, p. 15)
}

Na compreensão de Haug, em se tratando da economia política capitalista, "o subjetivo representa, ao mesmo tempo, o resultado e o pressuposto de seu funcionamento" (HAUG, 1997, p. 15). Nesse sentido, a materialidade é apreendida e interpretada, mas tendo como referências as interpretações subjetivas os sujeitos produzem novas transformações materiais, em uma relação na qual não faria sentido separar a produção material do espaço e a elaboração intelectual acerca desta materialidade. As paisagens como maneiras de ver configurar-se-iam como apreensões da realidade material pela intelectualidade humana, mas também como impulsionadoras de novas ações que transformam materialmente o espaço.

A interpretação do que foi apreendido pelos sentidos produz uma maneira de ver. Esta produção, conforme o entendimento que estamos adotando, tem nos referentes ideológicos um reservatório de ideias a partir das quais o indivíduo age e se posiciona perante o Mundo. Isso significa compreender que a produção das paisagens é algo permeado por ideologias, outro conceito caro para uma perspectiva crítica nas ciências. Historiando o conceito de ideologia, Lowy apresenta como origem do termo as formulações enciclopedistas de Destutt de Tracy, para o qual a ideologia se referia "ao estudo do relacionamento dos organismos vivos com o meio ambiente, onde trata das questões dos sentidos, da percepção sensorial, através da qual se chegaria às ideias" (LÖWY, 2015, p.18). Sabemos que o conceito de ideologia mais difundido nas abordagens críticas não é o do enciclopedismo francês, no entanto, consideramos pertinente trazê-lo para a reflexão na medida em que esta forma de conceber a ideologia guarda relação com aspectos como a percepção, os sentidos 
e a relação entre materialidade e produção das ideias; três aspectos caros para o conceito de paisagem tal como temos abordado.

Entre as perspectivas de ideologia posteriores a primeira formulação do conceito, destacamos a de Marx e Engels, mais consistentemente explicitada em Ideologia Alemã (MARX e ENGELS, 2007), que a concebem como "equivalente à ilusão, falsa consciência, concepção idealista na qual a realidade é invertida e as ideias aparecem como motor da vida real" (LOWY, 2015, p. 19). Sob esta perspectiva o termo ideologia assume uma conotação marcadamente negativa, que indicaria uma visão equivocada da realidade, ou "se refere à consciência deformada da realidade que se dá através da ideologia dominante: as ideias da classe dominante são as ideologias dominantes na sociedade" (Idem.). Sobre a recepção deste conceito no âmbito das abordagens geográficas, conforme Berdoulay

De certo modo, é a geografia cultural radical que, a pesar de ter utilizado pouco a noção e o termo em sua teorização, representa bem o que a inspiração marxista atribui à ideologia: uma função de mascaramento da realidade, uma representação falsa imposta pelas classes dominantes para facilitar sua dominação sobre as outras" (BERDOULAY, 2016, p. 112).

Ao analisarmos as considerações de Cosgrove (2004) sobre a relação entre paisagem, cultura e poder, verificamos que a caracterização supracitada de Berdoulay possui fundamento. A paisagem passa, no âmbito da geografia cultural radical, a expressar a hegemonia de valores da cultura dominante em uma determinada área, apresentando-se como uma maneira de ver que é assimilada como uma verdade geral sobre o que é observado, quando esta corresponderia a apenas uma das formas - a mais difundida, mas não única - de ler a realidade. O exemplo apresentado por Cosgrove, sobre a repercussão da cultura britânica em termos de paisagens, auxilia a compreender o que ele concebe como cultura dominante.

A cultura britânica é dominantemente inglesa em termos de área, burguesa em termos de classe, masculina em termos de sexo, branca em termos de cor e de meia-idade e anglicana em termos de religião. Tem uma paisagem característica, observável em todas as escalas, desde o interior das casas até o arranjo de regiões inteiras (COSGROVE, 2004, p. 227).

Quando destaca os aspectos dominantes na cultura como componentes da paisagem característica britânica, Cosgrove o faz partindo de uma compreensão que este domínio não é exercido exclusivamente a partir de posições de classe, mas também de gênero, das relações étnico-raciais, geracionais e religiosas. Esta cultura dominante se expressa materialmente: na construção de templos, no padrão construtivo das casas, na presença ou ausência dos corpos masculinos e femininos nas áreas públicas; mas também através da propagação dos referentes ideológicos a ela associados, condição para a consolidação de um poder que é

[...] mantido e reproduzido, até um ponto consideravelmente importante, por sua capacidade de projetar e comunicar, por quaisquer meios disponíveis e por todos os outros níveis e divisões sociais, uma imagem do mundo consoante com sua própria experiência e ter essa imagem aceita como reflexo verdadeiro da realidade de cada um" (Op. cit., p. 230).

Sobre a hegemonia de uma determinada visão de mundo sobre outras, esta se imporia, se adotamos uma perspectiva althusseriana, através dos aparelhos ideológicos de Estado (ALTHUSSER, 1980). A indústria cultural (ADORNO e HORKHEIMER, 1998), a partir da massificação de produtos como filmes, músicas e das propagandas, poderia ser outra forma de abordar a construção desta hegemonia de determinados referentes ideológicos sobre outros. Independentemente da abordagem que adotarmos neste quesito, importa compreender que a difusão da cultura dominante repercute na produção das paisagens e na sua recepção pelo observador/observadora como uma imagem 
associada a aspectos como a segurança ou insegurança de uma data localidade, sua relação harmoniosa ou conflitiva com a legislação urbana e ambiental e mesmo a percepção daquela área como sendo ordenada ou desordenada. Tais interpretações orientam a relação que as pessoas terão com aquela porção do espaço, uma relação que no espaço urbano é crescentemente permeada pela produção e consumo de mercadorias. Por isso, destacamos a seguir a relação entre as paisagens e mercadorias urbanas.

\title{
PAISAGEM, VALOR E A ESTÉTICA DAS MERCADORIAS
}

Para melhor explicitar sobre que mercadorias falaremos a seguir, iniciamos por destacar dois agentes produtores do espaço: os proprietários fundiários e os agentes do capital imobiliário. Do ponto de vista dos proprietários de terra, a atuação na cidade se objetiva obter uma maior renda fundiária com suas propriedades, pelo que se pode concluir que "estão fundamentalmente interessados no valor de troca da terra e não no seu valor de uso" (CORRÊA, 1995, p. 16). Na perspectiva de promotores imobiliários, a presença na cidade também é mediada pelo valor de troca, sendo que para estes a 0 objeto de venda deixa de ser a terra e sua renda, passando a ser a habitação, apartamento em prédio, ou casa em condomínio fechado, o instrumento para a realização do valor de troca sob a forma de dinheiro.

$\mathrm{Na}$ altura em que começamos a falar sobre valor de troca, convém sublinhar que

\begin{abstract}
O produto do trabalho é, em todas as condições sociais, objeto de uso, mas o produto do trabalho só é transformado em mercadoria numa época historicamente determinada de desenvolvimento: uma época em que o trabalho despendido na produção de uma coisa útil se apresenta como sua qualidade "objetiva", isto é, como seu valor. Segue-se daí que a forma de valor simples da mercadoria é simultaneamente a forma-mercadoria simples do produto do trabalho, e que, portanto, também o desenvolvimento da forma-mercadoria coincide com 0 desenvolvimento da forma de valor. (MARX, 2013, p. 192).
\end{abstract}

Como produto do trabalho, o desenvolvimento dos valores de troca ocorre paralelamente ao desenvolvimento da mercadoria. Destarte, recorrer à expressão "valor de troca" ao abordar a comercialização do solo urbano e dos imóveis é reconhecer a dimensão de mercadoria a eles associada.

Para que a realização do valor de troca aconteça, necessário é que aquilo que se comercializa - solo urbano, imóveis, mercadoria - apresente uma imagem que transmita ao comprador um potencial valor de uso, pois "a necessidade não possuidora de um precisa coincidir com a posse não necessária do outro" (HAUG, 1997, p. 23) para que as trocas se realizem, satisfazendo o valor de troca almejado pelo agente imobiliário/fundiário e possibilitando o uso para aquele que realiza a compra. Para a construção dessa imagem, cada vez mais necessária é a influencia da publicidade, do discurso em forma de imagem que informa ao comprador a expectativa do uso.

O uso desejado pelo comprador de uma determinada mercadoria somente se realiza quando de sua compra. Até sua efetivação, a expectativa do uso é informada por quem comercializa, utilizando a mediação das técnicas de publicidade e propaganda. Aqui, ganha destaque a "sedução" pela estética da mercadoria, que apela aos referentes ideológicos socialmente dominantes oferecendo mais do que o simples uso, uma experiência na cidade associada à ideia de sustentabilidade, contato com a natureza, conforto, segurança e praticidade. Inúmeras são as propagandas associando a venda de lotes de terra, apartamentos, que fazem uso dessas palavras "mágicas". De acordo com Haug, a estética da mercadoria "designa um complexo funcionalmente determinado pelo valor de troca e oriundo da forma final dada à mercadoria, de manifestações concretas e das relações sensuais entre sujeito e objeto por elas condicionadas [...]" (HAUG, 1997, p. 15).

A partir do conceito de estética da mercadoria podemos pensar a relação entre paisagem e valor de troca, pois como havíamos antecipado, "[...] a análise dessas relações possibilita o acesso ao lado 
subjetivo da economia política capitalista, na medida em que o subjetivo representa, ao mesmo tempo, o resultado e o pressuposto de seu funcionamento" (HAUG, 1997, p. 15).

As formulações de Haug vão ao encontro à preocupação de abordar a dimensão subjetiva das relações de produção. Em sua compreensão, a realização do valor de troca se dá com a elaboração de uma estética condizente com as aspirações subjetivas. Sua perspectiva não significa uma ruptura com o materialismo, pois considera o subjetivo primeiro como resultado da economia política capitalista; tampouco despreza a dimensão subjetiva das relações de produção, considerando esta o pressuposto para o funcionamento do sistema de produção material.

Trazendo para a Geografia as preocupações acima expostas, o conceito de paisagem torna-se relevante, pois na paisagem a construção da subjetividade é diversa, mas não ocorre desconsiderando os elementos concretos que se observa. Assim sendo, as maneiras de ver não se constroem a revelia da dimensão material, no entanto, a interação das pessoas com o mundo material tem como pressuposto as suas subjetividades.

Voltemos à relação entre paisagem e valor de troca. Como vimos, do ponto de vista de agentes imobiliários e fundiários, a relação como a cidade se dá tendo o valor de troca como finalidade e o valor de uso como mecanismo para alcançar tal fim. Pela estética da mercadoria, alcançamos a dimensão subjetiva das relações de troca, pela qual "o valor de uso estético prometido pela mercadoria torna-se então instrumento para obter dinheiro" (HAUG, 1997, p. 27). Ocorre que as mercadorias aqui discutidas são dotadas de atributos que as diferenciam de bens de consumo não duráveis, aparelhos eletrônicos ou gêneros alimentícios. É fácil perceber, quando se trata de comercializar chocolates, que a estética da mercadoria materializar-se-ia nas embalagens do produto e na propaganda, fazendo referência não só as qualidades do produto mas associando o mesmo a ideia de felicidade, prazer e bem-estar.

$\mathrm{Na}$ escala da cidade, mercadorias como prédios, terrenos e casas em condomínios são mais difíceis de embrulhar do que caixas de chocolate. Por isso, questionamos: qual a embalagem das mercadorias urbanas, sua estética enquanto mercadoria? Certo é que a propaganda nos meios de comunicação cumprirá um papel semelhante àquele desempenhado para a venda de mercadorias de menor porte. Comercias de TV destacando os atributos do empreendimento imobiliário, sua localização estratégica na cidade, tantas outras qualidades e também as "palavras mágicas" que associam o empreendimento aos valores da cultura dominante. Mas para que tais mercadorias transmitam a sensação de segurança, conforto, praticidade, é preciso mais que a propaganda informando tais atributos.

Para que a troca se realize, coforme o conceito de estética da mercadoria, é fundamental que a mercadoria expresse, aos olhos daquele que nela tenha interesse, a capacidade de atender ao uso esperado. Desta forma, a estética das mercadorias urbanas corresponde às maneiras de ver e, por conseguinte, aos referentes ideológicos que o agente imobiliário/fundiário julga serem aqueles que correspondem ao uso desejado pelo comprador.

Se não é possível embrulhar estas mercadorias, a própria paisagem em seu entorno deverá ser capaz de informar que o produto é sinônimo de conforto, praticidade, segurança, convívio com o que se convencionou chamar natureza, fácil mobilidade e tantos valores quantos forem capazes de proporcionar no comprador a expectativa em relação ao uso. As paisagens que são capazes de impulsionar a realização do valor de troca tal qual uma embalagem o é para produtos de menor porte, são a estética das mercadorias urbanas.

\section{A PAISAGEM COMO ESTÉTICA DAS MERCADORIAS NO SUDOESTE DO RECIFE}

Tomando a paisagem a partir da perspectiva crítica que expusemos, buscamos compreender a produção das maneiras de ver pelos agentes imobiliários e fundiários como parte da produção de uma estética das mercadorias urbanas, referenciada ideologicamente pela aproximação dos projetos propostos por esses agentes com ideias como: mobilidade urbana, sustentabilidade (reaproximação 
da natureza) e segurança. Para apresentar estas maneiras de ver valeremo-nos de projetos e pareceres apresentados aos conselhos de política urbana do Recife, imagens das peças publicitárias de empreendimentos do capital imobiliário e falas de seus representantes em reuniões oficiais e entrevistas.

O recorte empírico desta reflexão é o Sudoeste do Recife, composto por 16 bairros, a saber: Afogados, Areias, Barro, Bongi, Caçote, Coqueiral, Curado, Estância, Jardim São Paulo, Jiquiá, Mangueria, Mustardinha, San Martin, Sancho, Tejipió e Totó. Em termos administrativos, a cidade do Recife (figura 01) encontra-se dividida em seis Regiões Político Administrativas (RPA), sendo o Sudoeste do Recife correspondente a RPA 5 (em amarelo na figura).

Figura 01 - Regiões Político-Administrativas do Recife.

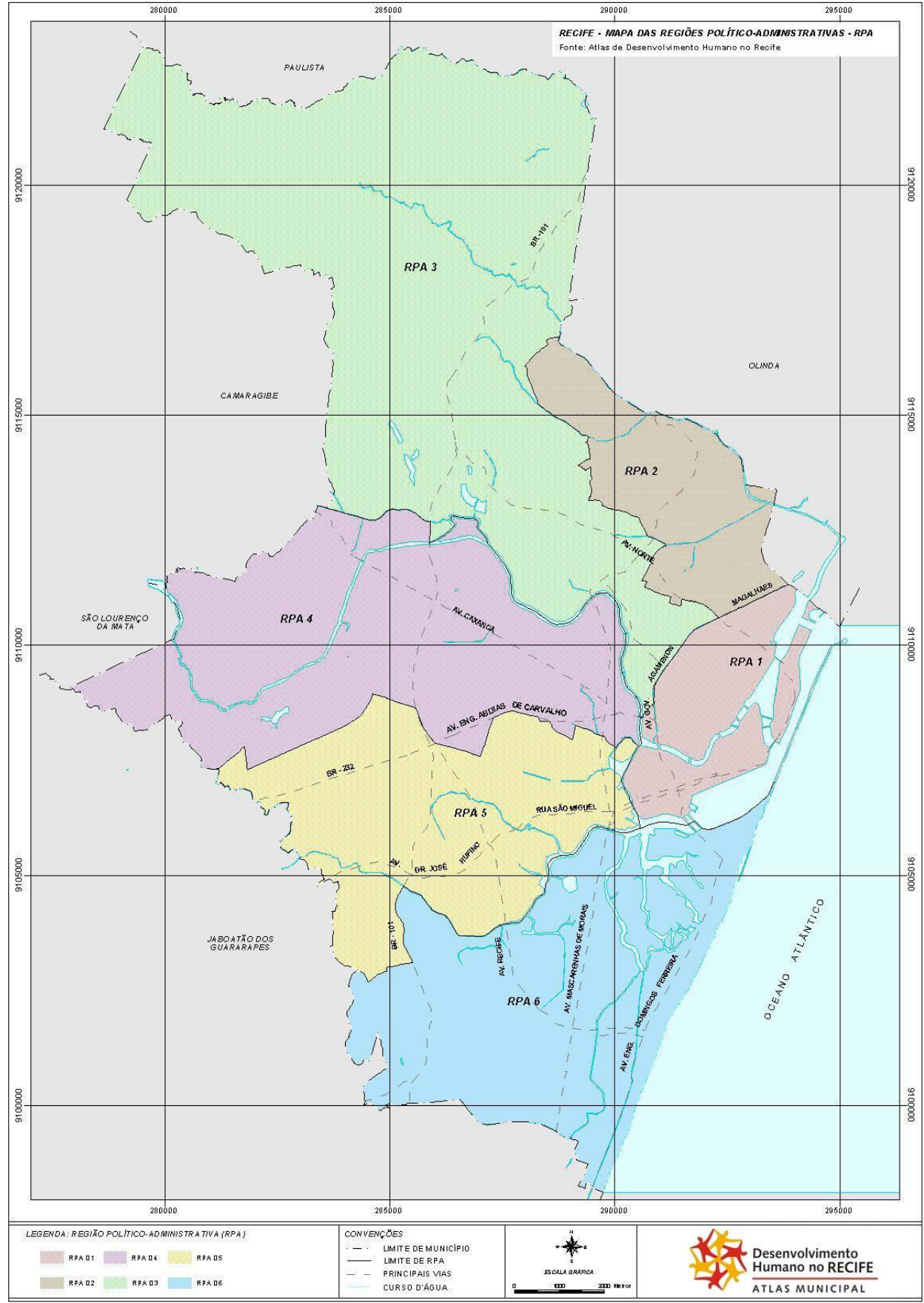

Fonte - Atlas do Desenvolvimento Humano do Recife. 
Há uma grande diversidade no interior de cada RPA no que diz respeito ao perfil socioeconômico e as características dos bairros. Contudo, a despeito dos limites para a compreensão da diversidade socioespacial que as estatísticas possuam, um dado nos parece de grande valia para compreender uma das especificidades da RPA 5 em comparação com as demais áreas da cidade. Diz respeito ao percentual de domicílios por faixa de renda em cada RPA (tabela 01). A partir deste dado é possível compreender o quadro econômico das famílias na região, que terá desdobramentos nas condições de moradia e valorização espacial da área.

Tabela 01 - Domicílios por classe de rendimento nas RPA do Recife (2010).

\begin{tabular}{|c|c|c|c|c|c|c|}
\hline $\begin{array}{l}\text { Classes de rendimento (em } \\
\text { Salários Mínimos) }\end{array}$ & RPA 1 & RPA 2 & RPA 3 & RPA 4 & RPA 5 & RPA 6 \\
\hline 0 até $1 / 4 \mathrm{SM}$ & $19,1 \%$ & $18,3 \%$ & $15,4 \%$ & $13,3 \%$ & $15,7 \%$ & $12,6 \%$ \\
\hline$>1 / 4$ até $1 / 2$ SM & $18,6 \%$ & $23,5 \%$ & $20,3 \%$ & $18,4 \%$ & $22,4 \%$ & $17,1 \%$ \\
\hline > $1 / 2$ até $1 \mathrm{SM}$ & $22,8 \%$ & $27,5 \%$ & $24,0 \%$ & $24,6 \%$ & $30,0 \%$ & $23,2 \%$ \\
\hline > 1 até 3 SM & $23,7 \%$ & $21,2 \%$ & $17,2 \%$ & $26,2 \%$ & $25,7 \%$ & $23,4 \%$ \\
\hline$>3$ até $10 \mathrm{SM}$ & $13,9 \%$ & $8,5 \%$ & $17,0 \%$ & $15,4 \%$ & $5,8 \%$ & $18,3 \%$ \\
\hline$>10 \mathrm{SM}$ & $2,0 \%$ & $1,1 \%$ & $6,0 \%$ & $2,2 \%$ & $0,3 \%$ & $5,4 \%$ \\
\hline № de domicílios & 25.385 & 64.977 & 94.977 & 86.527 & 75.495 & 120.562 \\
\hline
\end{tabular}

Fonte - MIRANDA (2014, p. 97), com dados do Censo 2010 (adaptado pelos autores).

Em números absolutos, durante aquele levantamento constatou-se que a RPA 5 é a quarta região político administrativa em quantidade de domicílios registrados. Analisando os dados isoladamente, seríamos levados a constatar que a RPA 1 possuía o maior percentual de domicílios cuja renda vai até um quarto (1/4) de salário mínimo, enquanto a RPA 2 detinha a liderança na faixa seguinte, de até metade do salário mínimo. A RPA 5 lideraria apenas na terceira faixa, com $30 \%$ dos domicílios entre 0,5 e 1 salário mínimo. No entanto, ao analisar os dados na sua totalidade, é possível concluir que a RPA 5 possuía o maior percentual de domicílios compreendidos entre as 3 primeiras classes de rendimento, que corresponderiam a $93,8 \%$ de todos os domicílios da RPA. Era também a RPA que possuía a menor quantidade de domicílios a partir de 3 salários mínimos em diante, que em valores absolutos totalizariam 4.605 espalhados por 16 bairros.

Se em 2010 os rendimentos em mais de 90\% dos domicílios da RPA 5 eram inferiores a 3 salários mínimos, evidentemente este fator colocava-se como condicionante das possibilidades de construir e reformar domicílios por parte dos moradores da região. Por um lado, visando o valor de uso tais reformas não necessariamente visam atribuir valor ao imóvel, mas, por outro lado, ao realizar a reforma (ou deixar de realizá-la) também condiciona o seu valor de troca, pois acresceria pela estética da paisagem valor à mercadoria espacial, no caso, pela valoração da paisagem local. Um condicionante que auxilia a compreender a relevância que teve e tem a autoconstrução nas paisagens do Sudoeste do Recife (figura 02), bem como o contraste entre estas formas e as proposições de agentes do capital imobiliário.

Figura 02 - Jardim São Paulo (Bairro da RPA 5), Recife, 2006.

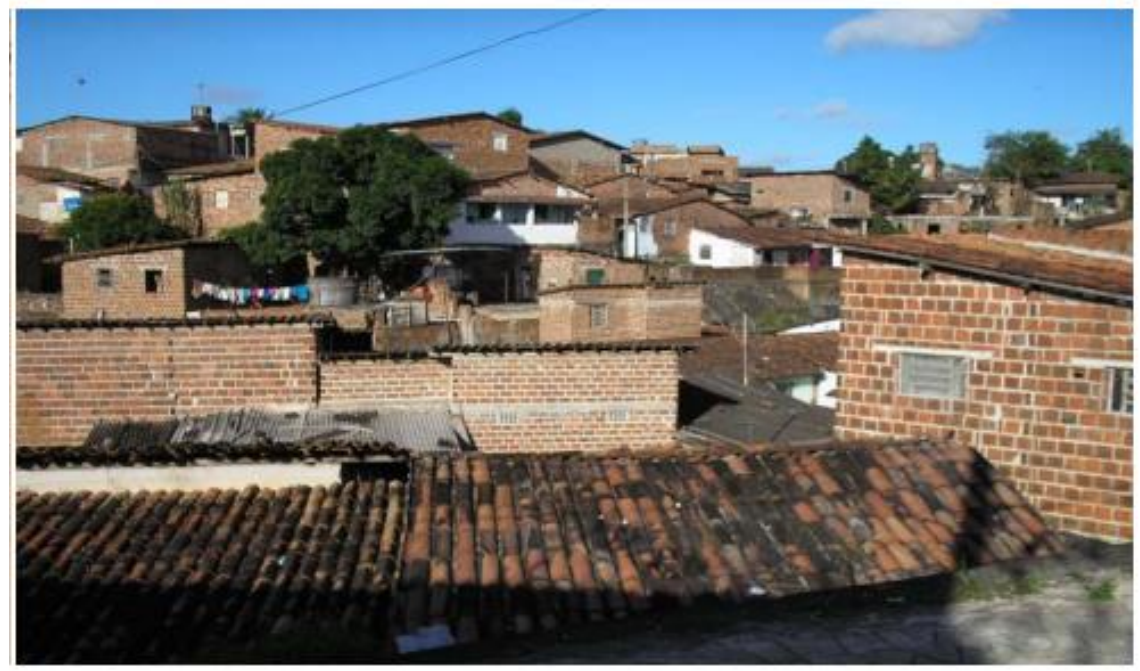

Fonte - SERRANO (2006). 
Os exemplos de maneira de ver que abordaremos situam-se nos bairros Jardim São Paulo, Jiquiá e Tejipió. Detivemo-nos inicialmente a dois empreendimentos: um condomínio residencial vertical e um shopping, planejados para o bairro Jiquiá. Os dois empreendimentos - o shopping e o condomínio se articulam, tendo sido apresentados ao poder público municipal ainda em 2011, que o qualificou como "bairro sustentável" e "um novo conceito de bairro, que vai integrar planejamento, conforto, lazer, praticidade e, principalmente, sustentabilidade". A associação com a ideia de sustentabilidade é perceptível em todas as ações de divulgação e peças publicitárias, a exemplo da logomarca (figura 03), que mescla tons de verde e azul em referência a cobertura vegetal e os cursos d'água próximos ao terreno.

Figura 03 - Logomarcas de empreendimentos previstos para a RPA 05.

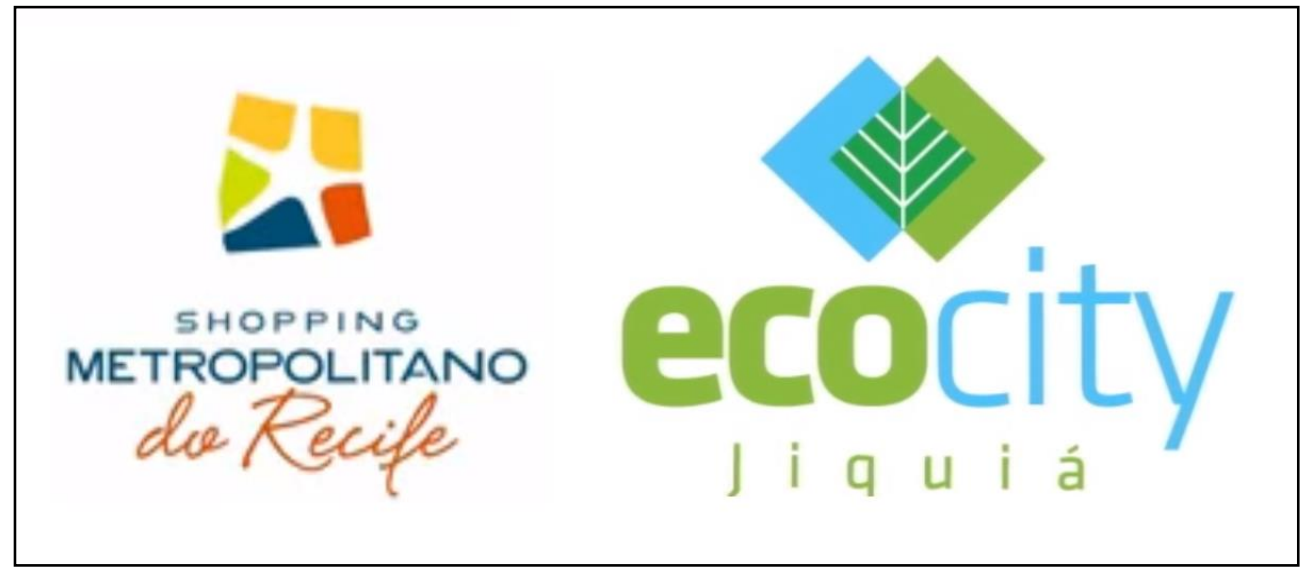

Fonte - Vídeos divulgação do EcoCity Jiquiá e Shopping Metropolitano. Disponíveis em: <https://www.youtube.com/watch?v=Xy6e7xnlEoY> e <https://www.youtube.com/watch?v=C-H_7IFm95M>. Acesso em 26 jun. 2016.

Para a construção estética e ideológica do valor do produto, houve uma preocupação em vincular a imagem dos empreendimentos à ideia de sustentabilidade. Tal preocupação acompanhou a criação das marcas, a elaboração dos projetos, as peças publicitárias e os documentos exigidos pelo poder público. No momento em que o projeto foi apresentado, a cobertura midiática o anunciava (CLUBE DA CONSTRUÇÃO CIVIL, 2018) como "primeiro bairro sustentável" ou "primeiro bairro planejado" do Recife, embora naquela altura nenhum documento formal tenha sido apresentado para tramitar nos órgãos públicos responsáveis. Esta preocupação de forte vinculação, a partir da publicidade, entre empreendimentos imobiliários e uma perspectiva de convivência com o verde, conexão com a natureza, também se revelou em projetos já consolidados (figura 04) e em andamento (figura 05), conduzidos por agentes imobiliários nos bairros Jardim São Paulo e Tejipió.

Figura 04 - Publicidade de empreendimentos concluídos em Jardim São Paulo e Tejipió, RPA 05 do Recife.

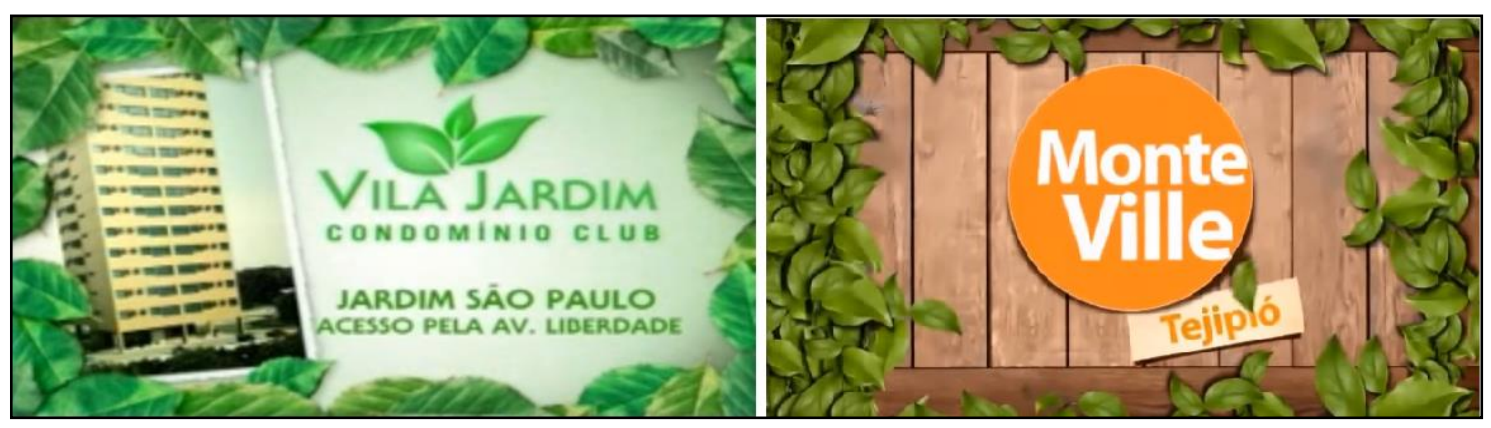

Fonte - Peças publicitárias dos empreendimentos imobiliários "Vila Jardim" e "Monte Ville". Disponíveis em: < https://www.youtube.com/watch?v=PzKClu5vXrc> e <https://youtu.be/nGTEJXFv9Yl>. Acesso em 05 mar. 2019. 
Em formato de comercial televisivo, as informações dos empreendimentos são apresentadas envoltas em folhas verdes, que compõem também a logomarca de um dos condomínios. A presença ostensiva de símbolos que associam os empreendimentos imobiliários à convivência com a natureza desnuda o uso da "sustentabilidade" como instrumento para valorização estética das mercadorias urbanas. Uma das propagandas chega a prometer "o melhor clima do Recife". Diante desta afirmação é possível dizer que "o valor de uso estético prometido pela mercadoria torna-se então instrumento para obter dinheiro" (HAUG, 1997, p. 27). Mais que um mecanismo de embelezamento, o que tais peças publicitárias prometem com um forte apelo ambiental é uma expectativa de valor de uso aos compradores: um habitar confortável em contraponto ao caos urbano, um habitar próximo ao verde em uma cidade acinzentada.

Figura 05 - Logomarca de empreendimento imobiliário no bairro Tejipió, RPA 5 do Recife.

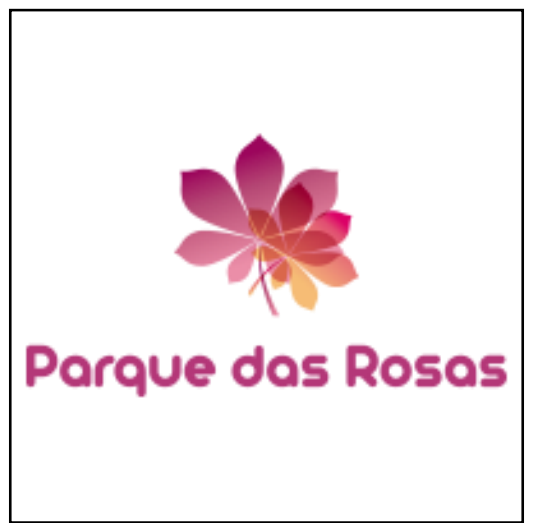

Fonte - Construtora Tenda. Disponível em <https://www.tenda.com/encontre-seu-imovel/pe/recife/parque-dasrosas>. Acesso em 05 mar. 2019.

A associação dos empreendimentos, através de suas logomarcas, com a ideia de "convivência com a natureza", repete-se no que ilustra a figura 05 , em mais um projeto de agentes imobiliários para 0 bairro Tejipió. Com exceção do condomínio previsto para o Jiquiá, todos os demais exemplos propõem condomínios fechados na RPA 05. Haverá, portanto, uma alteração da paisagem onde tais empreendimentos se consolidarem, sobretudo por serem em bairros onde a autoconstrução é mais presente. Mesmo o Ecocity Jiquiá (figura 06) representaria um grande desnível quando comparado ao entorno, onde casas com um ou dois pavimentos são predominantes na paisagem.

Os empreendimentos previstos para o Jiquiá nos permite tratar de outros aspectos associados às maneiras de ver. Em fala atribuída ao diretor de negócios da empresa responsável pelo projeto, este afirma: "vale ressaltar que não será um conjunto habitacional. Os prédios não serão iguais, nem haverá muros no bairro, pois estará totalmente integrado à cidade" (ASSOCIAÇÃO PERNAMBUCANA DE SHOPPING CENTERS, 2018). A fala ressalta a diferença entre um antigo projeto para a área - construção de habitacional para população de baixa renda - e a proposição do bairro planejado (figura 06). Ao sublinhar os aspectos que julga diferenciarem o seu projeto de um habitacional popular, o diretor avalia a ausência de muro como característica que faz o empreendimento estar "totalmente integrado à cidade".

Fazendo a leitura deste caso à luz dos conceitos e categorias que havíamos mencionado, é possível depreender das falas do diretor de negócios - como também na repercussão midiática - uma preocupação com a vinculação das mercadorias em discussão a uma estética que lhe associe ideias como sustentabilidade, integração com a cidade e facilidade de mobilidade. Isso está presente desde as logomarcas: a do shopping, com um estrela de cinco pontas, representando as cinco vias mais próximas do empreendimento (avenidas Recife, João Cabral de Melo Neto, 21 de Abril e as BR 101 
e 232); e a do condomínio residencial, que ressalta o prefixo "eco" e utiliza as cores verde e azul, em alusão a vegetação e ao rio que passa ao lado do terreno.

Por ainda estar apenas em fase de implementação, não seria possível concluir que tal empreendimento corresponderá de fato aos valores a que busca se associar no plano discursivo. Quantos carros, por exemplo, a existência de um shopping e de um condomínio naquela localidade acrescentaria ao fluxo diário nas vias do entorno? Esse acréscimo de veículos, em que pese às contrapartidas exigidas pelo poder público, teria impacto positivo na mobilidade? Da mesma forma, a impermeabilização de parte do terreno para as edificações, não traria prejuízos? Na fase inicial da proposição de qualquer projeto, não é possível obter tais respostas. No entanto, as peças publicitárias (figura 03), maquetes (figura 06) e os discursos dos empreendedores já sinalizam com assertividade características como a presença do verde, o conforto de morar "proximo da natureza". Tal ênfase justifica-se, em nosso entendimento pela necessidade, desde o ponto de vista do vendedor, de comunicar ao comprador através da estética da mercadoria uma expectativa de uso em conformidade com os padrões que este aspira. Dito de outro modo, a "aparência torna-se importante - sem dúvida importantíssima - na consumação do ato da compra, enquanto ser. O que é apenas algo, mas não parece um 'ser', não é vendável. O que parece ser algo é vendável" (HAUG, 1997, p. 26), pois "da perspectiva do valor de troca importa, até o final - ou seja, o fechamento do contrato de compra apenas o valor de uso prometido por sua mercadoria" (idem.). As peças publicitárias apresentadas e as logomarcas dos empreendimentos cumprem, portanto, o papel de prometer o valor de uso. As maquetes, como na figura 06, projetam a paisagem futura, dando destaque ao verde como componente da mesma, destaque fundamental para a transmissão da ideia de que as mercadorias ali expostas inspiram convivência com a natureza.

Figura 06 - Maquete virtual do "Ecocity Jiquiá".

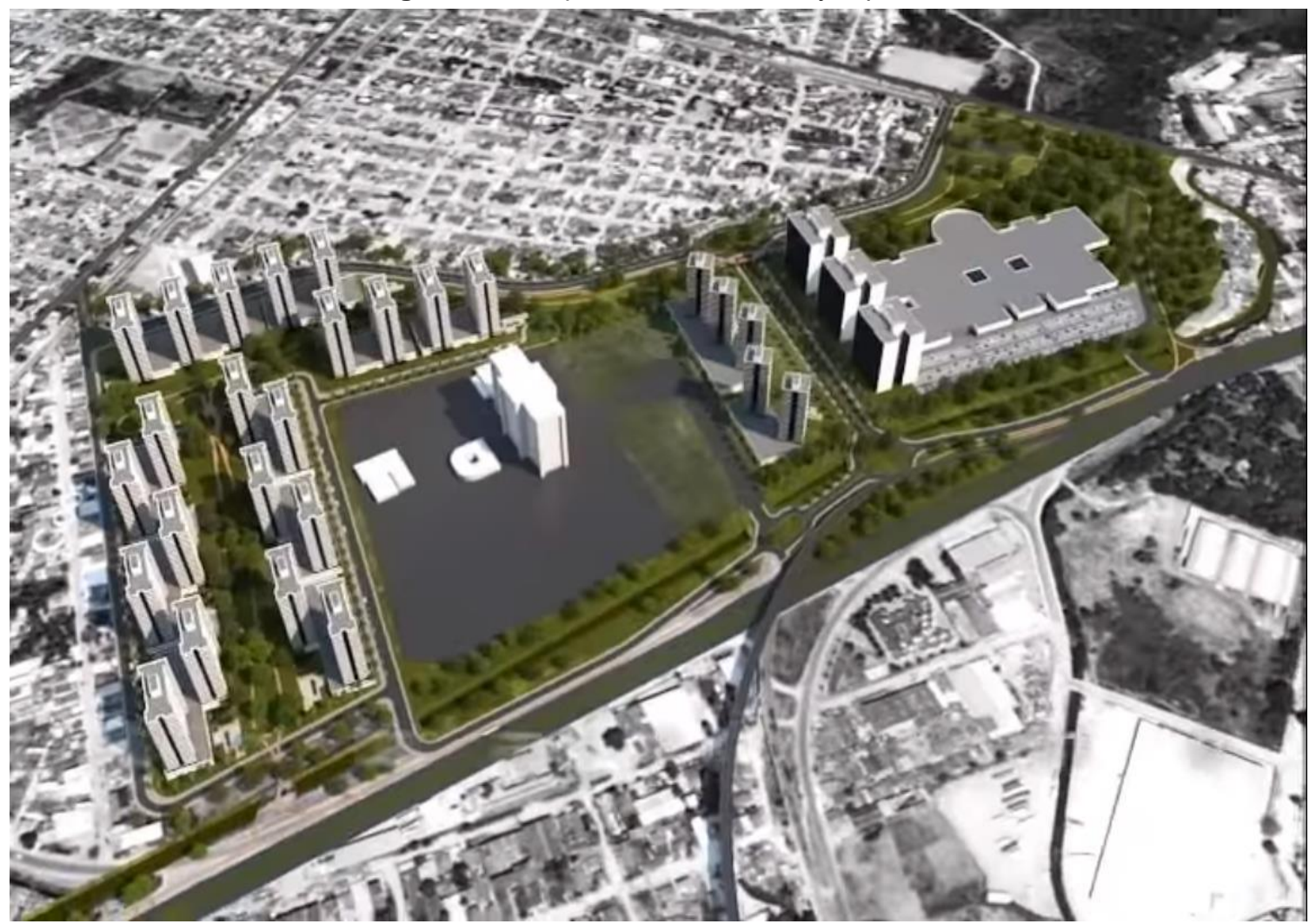

Fonte - Divulgação do EcoCity Jiquiá. Disponível em: <https://www.youtube.com/watch?v=Xy6e7xnIEoY>. Acesso em 27 jun. 2016. 
A maquete virtual do empreendimento fornece um panorama das áreas do seu entorno. Associada com a observação em campo é possível compreender a dinâmica da área e suas diferenças em relação ao projeto. Na figura 06, é possível observar na parte superior direita o início do Parque do Jiquiá e, ao seu lado direito a área onde se localizam as comunidades do Caxito e Cabeça de Vaca. Acima da área ocupada pela projeção do "bairro planejado", encontra-se uma área em cinza (como todo o entorno é representado) do bairro de San Martin, majoritariamente ocupada por casas originadas em autoconstrução e comércio de pequeno porte. Nesse sentido, ainda que a alegada ausência de muro corrobore para uma ideia de integração com a cidade, há uma grande diferença entre o padrão das habitações autoconstruída do entorno e os prédios que se projeta construir naquele terreno.

Estar integrado à cidade aparece aqui como argumento positivo em favor de um projeto sem muros, quando em outros empreendimentos a presença dos muros é sinônima de segurança e exclusividade, a exemplo dos condomínios fechados. Perceber esta distinção é importante para compreender que não existe um padrão único de intervenção por parte dos agentes imobiliários no que diz respeito à elaboração de propostas de paisagem. De acordo com os valores que se pretende destacar, a presença dos muros pode ser ou não conveniente para uma estética da mercadoria em conformidade com o produto anunciado e, por conseguinte, com a expectativa de realização do uso por parte dos futuros compradores.

Se o muro, por um lado, não contribui para uma ideia de integração à cidade, valor que os empreendedores pretendem associar ao projeto, torna-se uma importante ferramenta quando este ainda não está em execução, com a finalidade de estabelecer os limites de propriedade e inibir usos distintos daquele determinado ou permitido pelos proprietários. É o que ocorre contemporaneamente com o terreno destinado ao EcoCity e ao shopping. A contradição entre o discurso de um futuro empreendimento sem muros e o aumento do cercamento do terreno (figura 03) antes do início das construções expõe que há ali uma cerca perspectiva de integração a cidade, em detrimento de outras - como a das ocupações urbanas - que são interditadas pela presença do muro. Nesse quadro, convém resgatar o argumento de Cosgrove (2004), segundo o qual o poder também se reflete na paisagem "por sua capacidade de projetar e comunicar, por quaisquer meios disponíveis e por todos os outros níveis e divisões sociais, uma imagem do mundo consoante com sua própria experiência" (COSGROVE, 2004, p. 230). Deste modo, uma concepção de integração à cidade se projeta como sendo a capaz de dar àquele terreno um destino "sustentável", em conformidade com a lei e que sinalize a ideia de "progresso" para a localidade, como veremos em seguida.

Em registros realizados entre os meses de dezembro de 2011 - quando os empreendimentos são anunciados - e setembro de 2015 (figura 07) percebe-se uma mudança no entorno do terreno destinado à construção. Inicialmente, o terreno não possuía qualquer delimitação construída, passando a ser delimitado por um muro baixo em 2013, muro que é elevado entre os anos de 2013 e 2015. Convém mencionar que entre os anos de 2012 e 2013 - quando o poder público inicia as obras do Parque do Jiquiá (em frente ao futuro empreendimento) - parte da área destinada à construção de uma praça foi ocupada por moradias, que estabeleceram já naquele ano casas de alvenaria através de autoconstrução.

Paralelamente a esta primeira ocupação, que ocorre bem em frente ao terreno do futuro shopping, o primeiro muro é levantado. Entre os anos de 2013 e 2015, o muro baixo é elevado e circunda todo o terreno do empreendimento. Também neste período ocorre a Ocupação Olga Benário, que desta feita ocupa parte da área destinada ao projeto de bairro planejado. Nesse sentido, embora não haja confirmações, é grande a possibilidade de o muro ter se estabelecido como limite para evitar o avanço das ocupações para o terreno do empreendimento. Paralelamente a construção dos muros, a vigilância do terreno passa a ser realizada por pessoas contratadas com esta finalidade e aumenta a limitação de acesso ao mesmo, antes mais permeável à circulação e atividades de moradores do entorno. 
Figura 07 - Cercamento do terreno destinado aos empreendimentos.

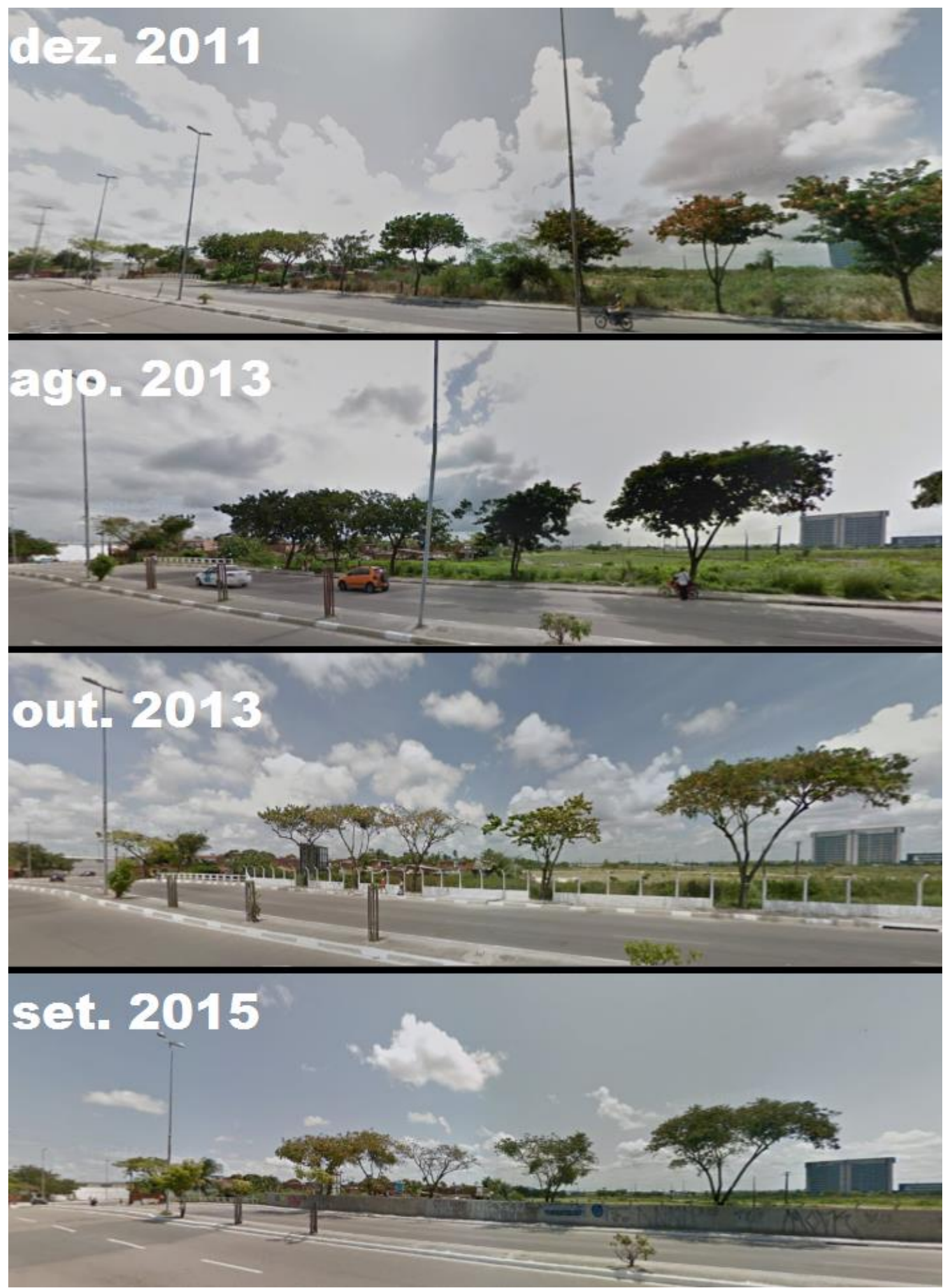

Fonte - Google Street View (2017).

No ano de 2017 pouco havia mudado em relação ao terreno, quando comparamos as imagens dos anos de 2015 e 2016 com as que registramos em campo (figura 08). Assim como nas imagens anteriores, apenas o prédio da Justiça Federal se destaca no terreno do empreendimento, enquanto 
as comunidades do Caxito e Cabeça de Vaca permanecem no local original. A permanência das comunidades, no entanto, tem sido objeto de discussão tanto por parte dos empreendedores, como foi objeto de discussão em audiência pública na Câmara Municipal.

Figura 08 - Registro do terreno destinado aos empreendimentos.

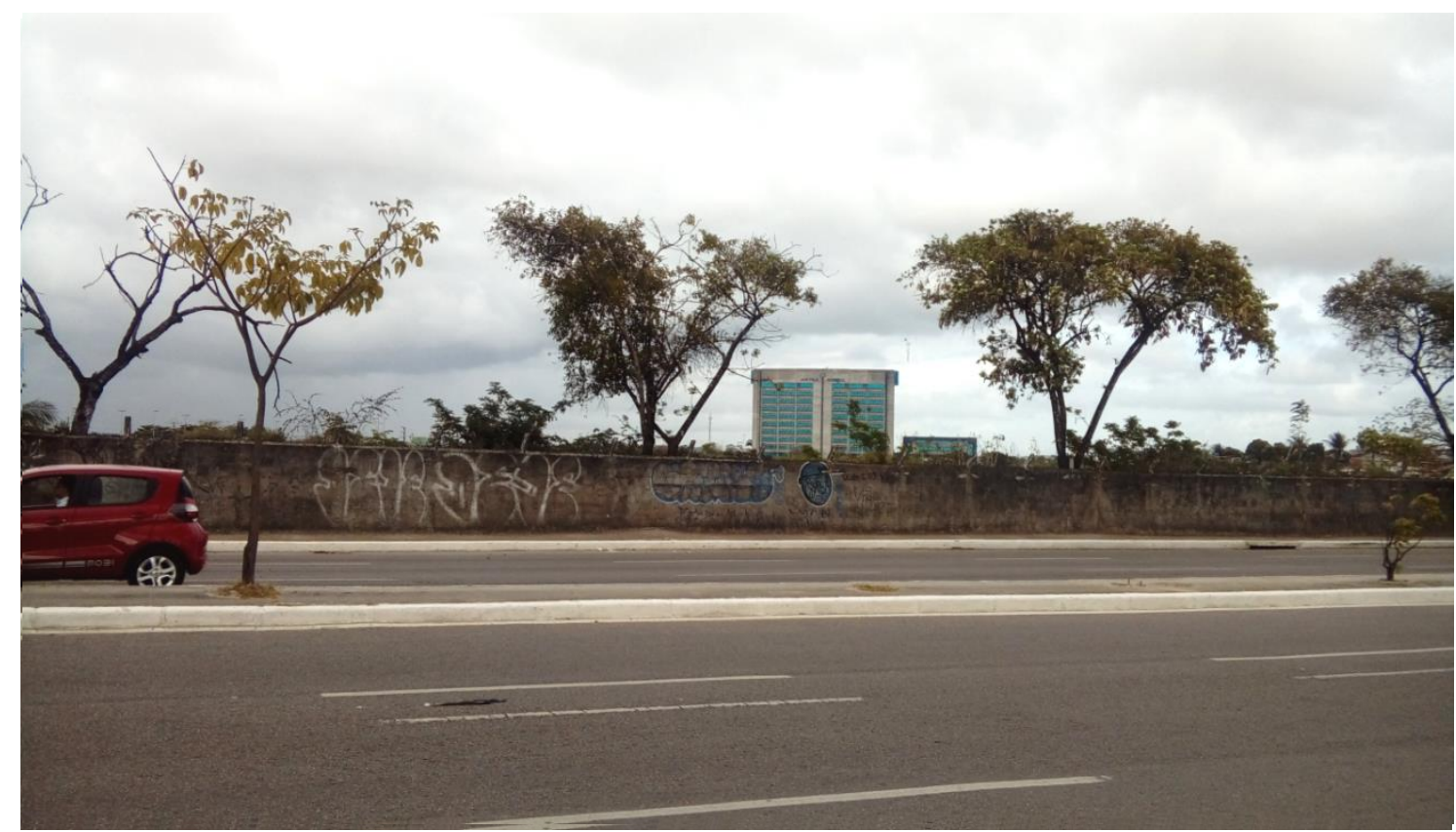

Fonte - fotografia do autor ( 2017).

Em julho de 2014, através de entrevista concedida ao jornal comunitário Infornativo, a assessoria de imprensa da empresa responsável pela construção do shopping manifestou sua leitura acerca da permanência das comunidades na proximidade do terreno. Quando perguntada sobre a necessidade de remoção de moradias para a realização das obras, a assessoria responde: "Haverá necessidade da desocupação da população que se encontra irregularmente instalada impedindo obras determinadas pelo Setor Público ao empreendedor" (INFORNATIVO, 2018a). Em seguida, quando perguntada se há algum levantamento sobre quantidade de residências que serão removidas e sobre as ações que a empresa pensa tomar para que ocorra a desocupação, responde:

São invasores que se estabeleceram sobre as margens do Rio Jiquiá e canais de drenagem desde 10 anos para cá, sob um olhar descompromissado das várias administrações municipais no que pese uma legislação ambiental definir tais ocupações como crime; [...] O Setor Público precisa atuar até porque a conta dessas doenças é maior que o esforço público de solução da questão de moradia. Ou seja, são 800 famílias que fizeram ocupação irregular na periferia do imóvel e que se sentem prejudicadas contra 160.000 famílias humildes em sua maioria, mas ordeiras, respeitadoras da legislação, pequenos empreendedores, que serão beneficiados fortemente pelo forte incremento da economia previsto para a região com o Ecocity Jiquiá (INFORNATIVO, 2018a).

Nas respostas da assessoria de imprensa dos empreendedores resta clara a caracterização que possuem sobre as comunidades próximas ao empreendimento: "ocupação irregular", "ocupação ilegal", "invasores" cuja ocupação se configura como "crime" perante a legislação ambiental. Há ainda uma diferenciação por parte do assessor que respondeu entre os que qualificou como "invasores" e as famílias "humildes em sua maioria, mas ordeiras, respeitadoras da legislação, pequenos empreendedores". Insalubre, irregular, ilegal, criminosa, degradante da áreas; os argumentos de que se vale o assessor para caracterizar as ocupações recuperam argumentos que de semelhante modo foram utilizados na perspectiva de combate aos mocambos do século XX do Recife, como os que apresentaram Pontual (2001) e Leite (2010). Por um lado, o discurso empresarial associa a paisagem dominada pelas autoconstruções ao desordenamento, irregularidades e degradação ambiental. Por 
outro, através das peças publicitárias e da estética das mercadorias, valores como a sustentabilidade e a mobilidade urbana são ressaltados e constam nas projeções das paisagens futuras.

Na sequência da entrevista, torna o assessor a utilizar a diferenciação entre invasores e ordeiros: "Há uma política de aproveitamento de mão de obra local sempre que formada por pessoas/famílias ordeiras e dentro da legalidade" (INFORNATIVO, 2018a). A informação é assimilada pelo discurso do parecerista que recomendou ao Conselho de Desenvolvimento Urbano (CDU) do Recife a aprovação do projeto: "[..]tem como prática [a empreendedora] investir na formação e desenvolvimento das pessoas que moram no entorno de seus empreendimentos, aproveitando-as para trabalharem durante o período de construção e depois nas lojas" (CDU, 2018). Esta informação associa-se a um componente forte no discurso empregado pelos responsáveis pelo empreendimento em seu favor: a criação de postos de trabalho e o envolvimento dos moradores e moradoras do entorno. Em outra reportagem, agora fala o co-presidente da empresa responsável pelo shopping:

O nosso compromisso é levar progresso, emprego e qualidade de vida às comunidades onde nossos shoppings estão localizados. Antes mesmo da construção, nos preocupamos em conhecer, a fundo, o comportamento e o perfil dos moradores da região, seus hábitos, cultura e demandas e seus sonhos (INFORNATIVO, 2018b).

No discurso de empreendedores e assessores das empresas recorrentemente aparecem palavras como "desenvolvimento", "progresso" e expressões como "incremento à economia", "desenvolvimento regional". Também com relação a este conjunto de palavras, é possível estabelecer um paralelo entre os referentes ideológicos que motivavam as ações de remoções dos mocambos sinônimos de atraso e insalubridade - e sua substituição por projetos habitacionais estatais consorciados com as construtoras. O progresso que aterrissava na década de 1930 no Campo do Jiquiá sob a forma de um Zeppelin (FIGUEIREDO, 2015), aterrissa uma vez mais, agora com um "bairro planejado", que se apresenta no plano do discurso como contraponto "sustentável" em relação às ocupações "irregulares". O progresso, em termos de paisagem, se realizaria pela substituição de uma estética que o discurso associou à degradação ambiental e irregularidades, por outra, que simbolize o inverso da primeira. Uma paisagem associada a irregularidades e degradação não contribuiria para a estética das mercadorias urbanas a serem instaladas.

Um último aspecto, no que concerne à posição dos agentes hegemônicos na produção do espaço urbano em Recife, encontra-se na mediação entre os interesses de tais agentes e a política urbana do município. Este obtido através de consulta ao parecer aprovado no CDU do Recife autorizando o início das obras do shopping, no qual o parecerista avalia que o empreendimento "[...] será um indutor do crescimento de nossa cidade para áreas ainda não habitadas, contribuindo para descentralização comercial e habitacional e a valorização imobiliária do entorno [...]"(RECIFE, 2018). O parecer acerca do shopping foi elaborado pelo conselheiro representante da Câmara de Dirigentes Lojistas (CDL) do Recife, alegando ser a área do empreendimento "não habitada", pelo que o parecer aparentemente desconhece a existência das ocupações consolidadas no entorno do terreno, as quais a própria empreendedora reconhece.

Em resumo, os representantes dos empreendimentos compreendem que a paisagem, conforme projetam, inspira valores como a integração com a cidade, sustentabilidade, incremento à economia local pela geração de empregos, ordem e planejamento; a assessoria de imprensa de uma das empresas contrapõe a estes valores as ocupações, qualificando-as como exemplos de desordem, desrespeito as leis e degradação do ambiente. Compõe o discurso dos empreendedores e de seus assessores a ideia de que o projeto se estabelece contribuindo para a população do entorno, consideração mais fortemente representada pelo discurso do copresidente da empreendedora. A assessoria de imprensa exacerba esta compreensão, afirmando que o projeto beneficiará 160 mil famílias, mas expõe uma contraposição entre o que considera famílias "humildes, mas ordeiras" e as 800 que "fizeram ocupação irregular" na extremidade do terreno, referindo-se às comunidades do Caxito e Cabeça de Vaca.

\section{CONSIDERAÇÕES FINAIS}

As reflexões que apresentamos partiram das maneiras de ver, constituídas por referentes ideológicos, para contribuir com a construção de uma abordagem crítica das paisagens na Geografia. Falamos em contribuir e não criar, porque na trajetória de nossas pesquisas encontramos na Geografia Cultural Radical um primeiro esforço nesta direção, pelo que reivindicamos a definição das 
paisagens por Cosgrove (2004), que as compreende como expressões de valores da cultura dominante, mas também como possibilidade expressão de culturas alternativas em uma trama onde poder e cultura são indissociáveis.

Buscamos no decorrer da reflexão articular a paisagem com perspectivas teóricas e conceitos próprios de abordagens críticas, tais como a dialética, as ideologias, valor de uso e troca e a estética das mercadorias. Concluímos com a articulação de conceitos ser possível interpretar as paisagens como estética de mercadorias urbanas, embalagens para produtos em comercialização nas cidades cuja finalidade seria, por um lado, transmitir aos compradores uma expectativa de valor de uso em conformidade com os referentes ideológicos da cultura dominante; e por outro, potencializar a realização do valor de troca.

Por fim, tendo como suporte empírico da discussão a proposição de empreendimentos privados no Sudoeste do Recife, interpretamos a produção das peças publicitárias, logomarcas, maquetes como parte da construção de uma perspectiva de paisagem, anunciada também no discurso dos representantes de agentes imobiliários e proprietários de terra. As maneiras de ver transmitidas nessas imagens e discursos associam os empreendimentos a valores como sustentabilidade, planejamento, integração com a cidade e desenvolvimento. Aqui percebemos a intencionalidade de produzir uma paisagem associada a um conjunto de referentes ideológicos, que sinalize tal como uma embalagem que os empreendimentos corresponderiam as expectativas de uso de seus potenciais compradores.

Ao mesmo tempo, os discursos dos representantes do empreendimento contrapõem a perspectiva de paisagem anunciada nas imagens com as ocupações urbanas presentes no entorno, tidas como irregulares, ilegais e provocadoras de degradação ambiental e problemas sanitários. Percebemos assim que a produção das imagens e outras formas de discurso acerca do que é regular e irregular, sustentável ou degradante, legal ou ilegal, seguro ou inseguro como parte de uma disputa pela cidade que se realiza no plano material, através da ocupação e compra de terrenos, mas também através de uma disputa no campo subjetivo sobre o significado de cada paisagem e sua conformidade/inconformidade com os padrões estéticos das mercadorias urbanas e, em ultima análise, com os próprios referentes ideológicos da cultura dominante.

\section{REFERÊNCIAS}

ADORNO, Theodor W.; HORKHEIMER, Max. Dialética de la llustración. Valladolid: Editorial Trotta 1998.

ALTHUSSER, Louis. Ideologia e Aparelhos Ideológicos de Estado. Lisboa: Editorial Presença, 1980.

ASSOCIAÇÃO PERNAMBUCANA DE SHOPPING CENTERS. Jiquiá terá o $1^{\circ}$ bairro planejado do Recife. APESCE, Recife, 2011. Disponível em: <http://www.apesce.com.br/noticias/?id=227>. Acesso em 28 jan. 2018.

BERDOULAY, Vincent. Espaço e Cultura. In: CASTRO, Iná Elias; CORRÊA, Roberto Lobato; GOMES, Paulo Cesar da Costa (Org.). Olhares Geográficos: modos de ver e de viver o espaço. Rio de Janeiro: Bertrand Brasil, 2012, p. 101-131.

CAPEL, Horacio. Filosofía y ciência en la Geografia contemporânea: Una introducción a la Geografía. Barcelona: BACANOVA, 1981.

CLUBE DA CONSTRUÇÃO CIVIL. Ecocity Jiquiá: o primeiro bairro sustentável do Recife. Clube da Construção Civil, Recife, 2014.2 Disponível em: <http://www.c3clube.com.br/site/conteudo/322-ecocity-jiquia-o-primeiro-bairro-sustentaveld.html>. Acesso 22 jan. 2018.

COSGROVE, Denis. A Geografia está em toda parte: Cultura e simbolismo nas paisagens humanas. In: CORRÊA, Roberto Lobato; ROSENDAHL, Zeny (Org.). Paisagem, Tempo e Cultura. Rio de Janeiro: EdUERJ, 2004, p. 92-123.

FIGUEIREDO, Jobson. Zeppelin no Recife. Recife: Poço Cultural, 2015. 
HAUG, Wolfgang Fritz. Critica da Estética da Mercadoria. São Paulo: Fundação Editora da UNESP, 1997.

INFORNATIVO. No Jiquiá: para que o progresso e a justiça social trilhem o mesmo caminho. Jornal Infornativo, Recife, 24 abr. 2014. Disponível em: <http://infornativo.com.br/no-jiquia-para-que-oprogresso-e-a-justica-social-trilhem-no-mesmo-caminho/>. Acesso em 22 jan. 2018b.

INFORNATIVO. Ecocity Jiquiá e Shopping Metropolitano e seus desdobramentos. Jornal Infornativo, Recife, 14 jul. 2014. Disponível em: <http://infornativo.com.br/ecocity-jiquia-e-shoppingmetropolitano-e-seus-desdobramentos/>. Acesso em 22 jan. 2018a.

KONDER, Leandro. O que é dialética. São Paulo: Brasiliense, 2008.

LEITE, Ricardo. Recife dos Morros e Córregos: a fragorosa derrota do exterminador de mocambos e sua liga social em Casa Amarela. In: Encontro Nacional de História Oral, 10, 2010, Recife. Anais eletrônicos. Recife: UFPE, 2010. Disponível em: < https://www.encontro2010.historiaoral.org.br/resources/anais/2/1270423029_ARQUIVO_RECIFED OSMORROSECORREGOS.05012010.pdf >. Acesso em 18 mar. 2019.

LOWY, Michel. Ideologias e Ciência Social: elementos para uma análise marxista. São Paulo: Cortez, 2015.

MARANDOLA JR., Eduardo. Humanismo e Abordagem Cultural em Geografia. GEOGRAFIA. Rio Claro, v. 30, n. 3, set./dez, p. 393-419, 2005.

MARX, Karl. O Capital: Crítica da economia política. Livro I: O processo de produção do capital. Tradução: Rubens Enderle. São Paulo: Boitempo, 2013.

MARX, Karl; ENGELS, Friedrich. A Ideologia Alemã. São Paulo: Boitempo, 2007.

MIRANDA, Georgia Cavalcanti Alves de. Saneamento básico na cidade do Recife: entre a idealidade do planejamento e realidade da execução. 2014. Dissertação (Mestrado). Programa de Pós-Graduação em Desenvolvimento Urbano, Centro de Artes e Comunicação, Universidade Federal de Pernambuco, Recife, 2014.

MORAES, Antonio Carlos Robert. Ideologias Geográficas. 5 ed. São Paulo: Annablume, 2005.

PAULO NETTO, José. Introdução ao estudo do método de Marx. 1ํㅡ. ed. São Paulo: Expressão Popular, 2011.

PONTUAL, Virgínia. Tempos do Recife: representações culturais e configurações urbanas. In: Revista Brasileira de História. São Paulo, v. 21, n. 42, p. 417-434, 2001. https://doi.org/10.1590/S0102-01882001000300008

RECIFE. Câmara de Dirigentes Lojistas do Recife. Parecer processo: 07.34435.8.11. Recife: Câmara de Dirigentes Lojistas do Recife, 12 nov. 2014. Disponível em: <http://licenciamento.recife.pe.gov.br/sites/default/files/Parecer\%20do\%20Projeto\%20do\%20Sh opping\%20Metropolitano,\%20no\%20Jiquiá..pdf>. Acesso em 31 jul. 2018.

SERRANO, Maria José Vitoriano; CASTILHO, Claudio Jorge Moura de. Planeta dos Macacos: A negação do pertencer ao lugar e suas implicações na construção do espaço do cidadão. 2006. Dissertação (Mestrado). Programa de Pós-Graduação em Geografia, Universidade Federal de Pernambuco, Recife, 2006.

Recebido em: 02/10/2018

Aceito para publicação em: 30/05/2019 